\title{
INTEROPERABILNOST ZAPISA OCJENSKIH RADOVA U DABRU
}

\author{
THE INTEROPERABILITY \\ OF E-THESES RECORDS IN DABAR
}

\author{
Karolina Holub \\ Nacionalna i sveučilišna knjižnica u Zagrebu \\ kholub@nsk.hr \\ Ljiljana Jertec \\ Sveučilišni računski centar Sveučilišta u Zagrebu (SRCE) \\ Ljiljana.Jertec@srce.hr
}

UDK / UDC 005.92:004.63

Stručni rad / Professional paper

Primljeno / Received: 9. 4. 2018.

Prihvaćeno / Accepted: 4. 6. 2018.

\section{Sažetak}

Cilj. Cilj je ovog rada upoznavanje knjižničarske zajednice sa sustavom za obradu, pohranu i objavu ocjenskih radova u digitalnom obliku. Posebno je naglašen radni proces za pohranjivanje radova u repozitorije u Dabru koji je baziran na automatiziranom preuzimanju velikog broja podataka iz različitih sustava kako bi se u najvećoj mogućoj mjeri olakšao i ubrzao unos, osigurala točnost te smanjila redundantnost podataka. Za opis radova koristi se osnovni set elemenata Dublin Core te detaljnija, hijerarhijski organizirana metapodatkovna shema MODS koja se sastoji od elemenata, podelemenata i atributa koji ih dodatno opisuju. Kako bi se zapisi ocjenskih radova uspješno razmjenjivali s drugim sustavima, svaki zapis dostupan je putem OAI-PMH-sučelja pojedinog repozitorija u Dabru.

Pristup/metodologija/dizajn. Rad je informativnog karaktera i objašnjava načine rada u sustavu Dabar, ali i zakonski okvir ustanova koje su obveznici dostave i pohrane radova.

Vjesnik bibliotekara Hrvatske 61, 1(2018), 489-508

ISSN 0507-1925

(C) VBH 2018. 
Rezultati. $U$ radu su navedeni statistički podaci o količini pohranjenih i dostupnih ocjenskih radova kroz Nacionalni repozitorij završnih i diplomskih radova (ZIR), odnosno Nacionalni repozitorij disertacija i znanstvenih magistarskih radova (DR), te statistički podaci posjećenosti navedenih repozitorija. Naveden je popis sustava iz kojih repozitoriji u sustavu Dabar preuzimaju metapodatke i radove, kao i popis sustava putem kojih su zapisi repozitorija dostupni.

Praktična primjena. Rad je namijenjen svim knjižničarima i IT-stručnjacima koji su uključeni u rad s repozitorijima i imaju obavezu dostave i pohrane ocjenskih radova.

Originalnost/vrijednost. Uz osnovne procese s kojima su knjižnice do sada bile upoznate, radom se željelo upoznati s naprednim mogućnostima razmjene koje sustav pruža, ali i dati informacije o vanjskim sustavima u kojima se mogu pronaći hrvatski ocjenski radovi u digitalnom obliku.

Ključne riječi: DABAR, DR, interoperabilnost, ocjenski radovi, ZIR

\section{Abstract}

Purpose. The aim of the paper is to acquaint the library community with a system for processing, storing and publishing e-theses and e-dissertations. The workflow for storing digital objects in repositories in the DABAR system is based on automated data exchange from different systems to facilitate and accelerate the process of entering data, to ensure accuracy and reduce data redundancy. Digital objects in DABAR are described with the Dublin Core metadata elements and the more detailed metadata scheme MODS, which includes elements, sub-elements, and attributes for additional details. In order to facilitate the e-theses records exchange with other systems, each DABAR record is available through the OAI-PMH interface.

Approach/methodology/design. The paper explains the work processes and methods in DABAR as well as the legal framework which obliges institutions to store e-theses and e-dissertations.

Findings. The paper presents statistical data on the number of stored and available e-theses and e-dissertations in Croatian Digital Theses Repository (ZIR) and Croatian Digital Dissertations Repository (DR) as well as statistical data on the usage of these repositories. The paper also lists other systems with which repositories in the DABAR system can exchange metadata and documents, and the list of protocols for record retrieval.

Practical implications. The paper is useful for librarians and IT specialists involved in storing objects in digital repositories and are required to submit and store e-theses.

Originality/value. Along with the procedures already in use in libraries, the paper presents the advanced possibilities of metadata exchange in DABAR. It also provides the information on the external systems in which the Croatian e-theses and e-dissertations can be found.

Keywords: DABAR, DR, e-dissertations, e-theses, interoperability, ZIR 


\section{Uvod}

Ocjenski radovi ${ }^{1}$ predstavljaju vrstu građe koju akademske ustanove obrađuju i čuvaju u svojim zbirkama. U svijetu početak razvoja repozitorija koji se bave prihvatom, obradom, pohranom i davanjem na korištenje ocjenskih radova $\mathrm{u}$ digitalnom obliku, tzv. ETD (Electronic theses and dissertations), datira od početka 1990-ih godina. U razvoju takvih sustava najviše su odmaknula visoka učilišta u Sjedinjenim Američkim Državama kao što je visoko učilište Virginia Tech University koje je, među ostalim, razvilo softver za prihvat diplomskih radova i disertacija u digitalnom obliku. Isto sveučilište zajedno s partnerima na drugim američkim sveučilištima 1996. uspostavlja mrežu repozitorija National Digital Library of Theses and Dissertations (NDLTD) u koju se vrlo brzo uključuju i druge zemlje, čime mreža postaje međunarodnog karaktera i mijenja naziv u Networked Digital Library of Theses and Dissertations. ${ }^{2}$ Do danas su u NDLTD uključeni i mnogi europski digitalni repozitoriji sa svojim metapodacima (EThOS, DiVA itd.). ${ }^{3}$

U Hrvatskoj su do 2013. podaci o ocjenskim radovima bili dostupni isključivo putem kataloga knjižnica - nacionalne, visokoškolskih i specijalnih - za tiskani oblik rada, dok su podaci o ocjenskim radovima u digitalnom obliku bili dostupni u iznimno rijetkim institucijskim repozitorijima pojedinih visokoškolskih ustanova - Repozitorij fakulteta strojarstva i brodogradnje Sveučilišta u Zagrebu, Repozitorij Medicinskog fakulteta Sveučilišta u Zagrebu, DARHIV, Središnja knjižnica za fiziku itd. ${ }^{4}$

Nacionalna i sveučilišna knjižnica u Zagrebu u svom fondu sadrži preko 35 000 doktorskih i znanstvenih magistarskih radova u tiskanom obliku obranjenih na hrvatskim sveučilištima (Zagreb, Rijeka, Split, Osijek, Pula, Zadar, Dubrovnik). ${ }^{5}$ Kako bi očuvala i učinila dostupnim najstarije disertacije Sveučilišta u Zagrebu, NSK je 2009. i 2010. digitalizirala 100 najstarijih disertacija u sklopu projekta Ministarstva kulture, a 2011. uspostavljen je sustav za obradu, pohranu i davanje na korištenje te vrste znanstvenih radova - Digitalni akademski repozitorij (DAR). ${ }^{6}$ Navedeni sustav više se ne razvija i sadržaj mu se ne osuvremenjuje.

\footnotetext{
1 Termin „ocjenski radovi“ obuhvaća sve vrste radova obranjene na hrvatskim sveučilišnim i stručnim studijima, a to su završni i diplomski radovi, kao i disertacije te znanstveni magistarski radovi

2 Networked Digital Library Of Theses And Dissertations (NDLTD). [citirano:2018-03-20]. Dostupno na: http://www.ndltd.org/.

3 Popis repozitorija dostupan je na adresi http://union.ndltd.org/portal/.

4 Konjević, S. Ocjenski radovi u digitalnom obliku. // Kemija u industriji, 59, 9(2010), str. 455.

5 Podaci o broju radova dostupni su u Zbirci disertacija i magistarskih radova NSK (http://www. nsk.hr/disertacije-i-magistarski-radovi/).

6 DAR. [citirano: 2018-03-15]. Dostupno na: http://dar.nsk.hr/.
} 


\section{Sustav Digitalnih akademskih arhiva i repozitorija}

Od srpnja 2013. godine u Republici Hrvatskoj na snazi je Zakon o izmjenama i dopunama Zakona o znanstvenoj djelatnosti i visokom obrazovanju ${ }^{7}$ koji u članku 40 propisuje da su

„Završne radove studija sveučilišta i fakulteti dužni (...) trajno objaviti na javnoj internetskoj bazi sveučilišne knjižnice u sastavu sveučilišta te kopirati u javnu internetsku bazu završnih radova Nacionalne i sveučilišne knjižnice." 8

S obzirom na to da veleučilišta i visoke škole nisu sastavnice sveučilišta, njihova je obaveza da završne radove pohranjuju izravno u javnu internetsku bazu završnih radova Nacionalne i sveučilišne knjižnice. ${ }^{9}$ Za završne radove umjetničkih studija koji se realiziraju kroz umjetnička ostvarenja Zakon propisuje da se „objavljuju (...) na odgovarajući način“. ${ }^{10}$

Za postupanje s disertacijama u digitalnom obliku propisano je da je iste „visoko učilište dužno (...) trajno objaviti na javnoj internetskoj bazi doktorskih disertacija Nacionalne i sveučilišne knjižnice"11,

dok je sveučilište obvezno dostaviti tiskani primjerak disertacije Nacionalnoj i sveučilišnoj knjižnici u Zagrebu. ${ }^{12}$

Kako bi se ujednačili opisi i omogućilo drugim knjižnicama koje nisu u mogućnosti ni ljudstvom ni financijski osigurati prihvat, obradu, pohranu i korištenje ocjenskih radova u digitalnom obliku, NSK i Srce zajedno s nekoliko knjižnica visokih učilišta i iz sustava znanosti 2014. godine započinju rad na sustavu za izgradnju institucijskih repozitorija.

Dabar je sustav digitalnih akademskih arhiva i repozitorija koji svim ustanovama iz sustava znanosti i visokog obrazovanja osigurava infrastrukturu potrebnu za uspostavu institucijskih repozitorija. ${ }^{13}$ Brigu o računalnim resursima, sigurnosti podataka, razvoju funkcionalnosti, nadogradnjama i održavanju svih repozitorija u Dabru vodi Srce. Otvaranjem institucijskog repozitorija u Dabru ustanove dobivaju repozitorij na željenoj internetskoj domeni ustanove uz punu kontrolu nad ovlastima u repozitoriju, kao i nad time što će se pohranjivati te pod kojim uvje-

\footnotetext{
Zakon o izmjenama i dopunama Zakona o znanstvenoj djelatnosti i visokom obrazovanju. // Narodne novine 94, 2132(2013). [citirano: 2018-03-20]. Dostupno na: http://narodne-novine. nn.hr/clanci/sluzbeni/2013_07_94_2132.html.

8 Isto.

9 Isto.

10 Isto.

11 Isto.

12 Isto.

13 Dabar. [citirano: 2018-04-05]. Dostupno na: https://dabar.srce.hr/.
} 
tima pristupa i korištenja. Sustav je pušten u produkcijski rad u kolovozu 2015. godine, a do ožujka 2018. godine uspostavlja se 121 repozitorij (slika 1). ${ }^{14}$

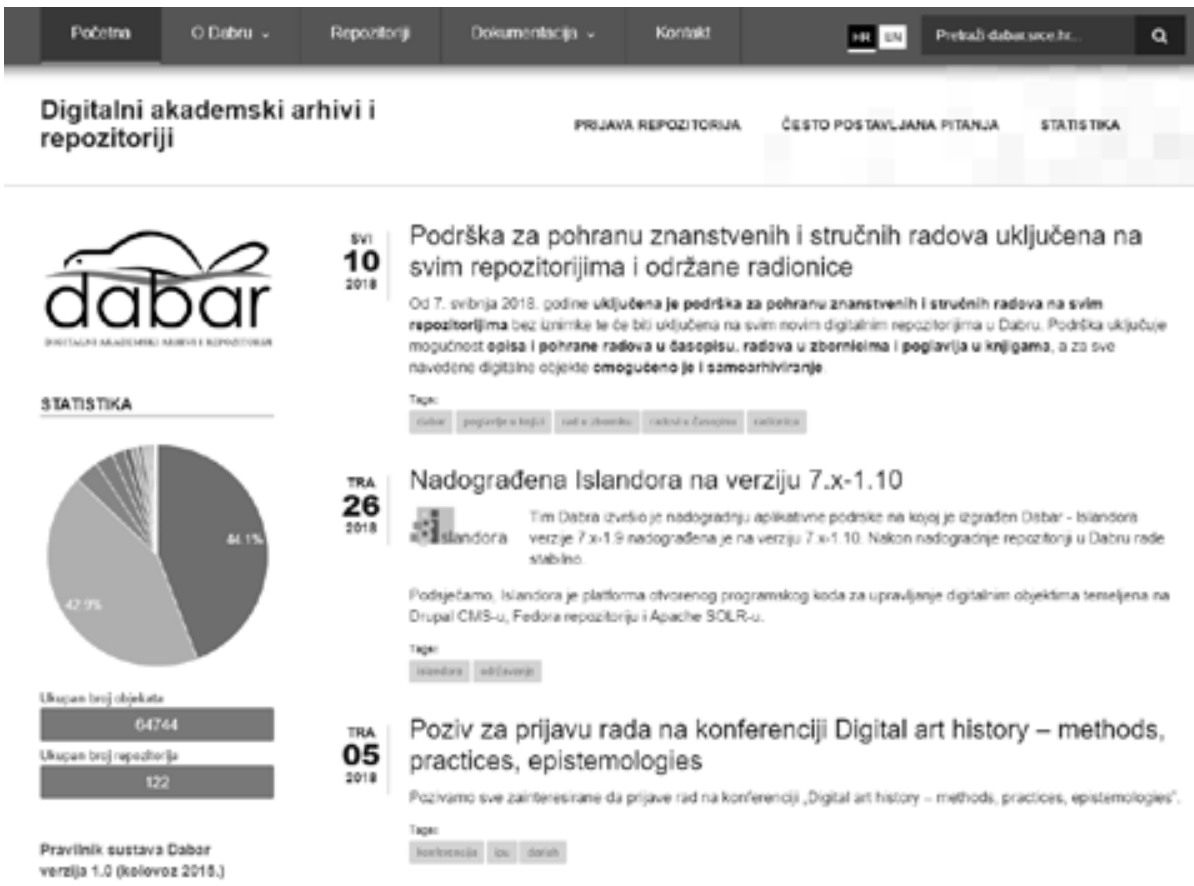

Slika 1. Naslovnica Dabra

Zbog navedene zakonske obveze visokih učilišta, inicijalni digitalni objekti koje se moglo pohranjivati u repozitorije odmah po puštanju u produkcijski rad bili su završni, diplomski i specijalistički radovi, a nešto kasnije iste godine implementirana je i podrška za pohranu znanstvenih magistarskih radova i doktorskih disertacija. Imajući u vidu da će Dabar koristiti potencijalno velik broj ustanova te da će potrebe ustanova po pitanju pohrane i upravljanja digitalnom građom samo rasti, jedan od osnovnih uvjeta koje je Dabar trebao ispunjavati bila je mogućnost „da se sustav može proširiti u skladu s potrebama hrvatske istraživačke i akademske zajednice i integrirati s postojećim i budućim sustavima u Hrvatskoj, a po potrebi i šire“..$^{15}$

14 Podaci o broju repozitorija dostupni su na stranicama Dabra: https://dabar.srce.hr/stats.

15 Celjak, D.; Z. Bekić; Lj. Jertec; M. Milinović; D. Ulamec. Dabar - sustav digitalnih repozitorija: iskorak prema sustavnoj brizi za digitalnu imovinu akademske zajednice u Hrvatskoj. // Arhivi, knjižnice, muzeji 18(2015), str. 153. [citirano: 2018-04-05]. Dostupno na: https://hrcak.srce.hr/ ojs/index.php/akm/article/view/3746. 
Kako bi ispunila svoju zakonsku obvezu, NSK u suradnji sa Srcem u ljeto 2015. uspostavlja Nacionalni repozitorij završnih i diplomskih radova (ZIR) ${ }^{16}$ (slika 2), a u prosincu 2015. Nacionalni repozitorij disertacija i znanstvenih magistarskih radova (DR). ${ }^{17}$

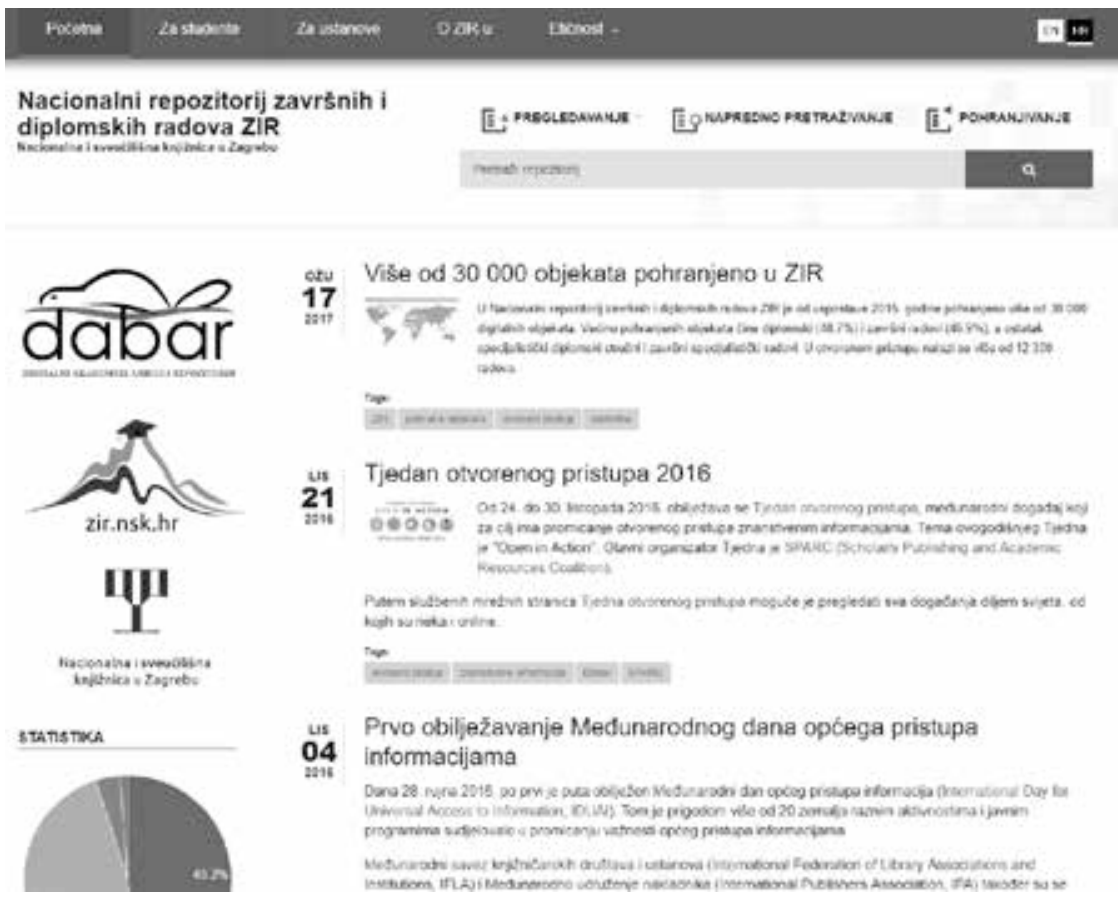

Slika 2. Naslovnica Nacionalnog repozitorija završnih i diplomskih radova (ZIR)

Uspostavom repozitorija osigurava se trajna pohrana i omogućuje javni pristup svim ocjenskim radovima u digitalnom obliku obranjenim u Republici Hrvatskoj. Nacionalni repozitoriji objedinjuju sadržaje svih repozitorija ocjenskih radova u Republici Hrvatskoj.

\section{Repozitoriji ocjenskih radova}

Visoko obrazovanje u Hrvatskoj obuhvaća stručne i sveučilišne studije. Sveučilišnim studijima obuhvaćene su sljedeće razine: preddiplomski, diplomski i integrirani preddiplomski i diplomski studij, poslijediplomski specijalistički studij te poslijediplomski studij, dok stručni studiji obuhvaćaju kratki stručni studij, preddiplomski stručni studij i specijalistički diplomski stručni studij.

16 Nacionalni repozitorij završnih i diplomskih radova (ZIR). [citirano:2018-03-15]. Dostupno na: https://zir.nsk.hr/.

17 Nacionalni repozitorij disertacija i znanstvenih magistarskih radova (DR). [citirano:2018-03-15]. Dostupno na: https://dr.nsk.hr/. 
Vrste radova koje je moguće pronaći putem Nacionalnog repozitorija završnih i diplomskih radova (ZIR) jesu svi obranjeni, obrađeni i pohranjeni završni i diplomski radovi ${ }^{18}$ na hrvatskim visokim učilištima - fakultetima, veleučilištima i visokim školama. Sadržaj koji se trenutačno može pronaći na portalu ZIR koncipiran je u nekoliko izbornika i namijenjen je studentima, djelatnicima ustanova i svima koji su na neki način uključeni u proces dostave, pohrane i objave ocjenskih radova. Na portalu posebno mjesto zauzima i izbornik o znanstvenoj čestitosti i etičkim kodeksima. U sklopu Nacionalnog repozitorija disertacija i znanstvenih magistarskih radova (DR) moguće je pronaći disertacije u digitalnom obliku, obranjene, obrađene i pohranjene u repozitorijima hrvatskih sveučilišta. Uz suvremene ocjenske radove, nacionalni repozitoriji prikupljaju i pohranjuju i starije digitalizirane diplomske radove, disertacije i znanstvene magistarske radove.

Ključni elementi za upravljanje digitalnom građom jesu ispravno opisan sadržaj i dobro strukturirani metapodaci, čime je omogućeno pronalaženje i dostupnost, ali i njihova kvalitetna razmjena između više sustava. U okviru dostave i pohrane radova u Nacionalni repozitorij završnih i diplomskih radova (ZIR), odnosno Nacionalni repozitorij disertacija i znanstvenih magistarskih radova (DR), Nacionalna i sveučilišna knjižnica u Zagrebu je, u suradnji sa Srcem i drugim partnerskim ustanovama, sastavila metapodatkovni opis završnih i diplomskih radova ${ }^{19}$ te opis disertacija. ${ }^{20}$ Specifikacije metapodatkovnih opisa navedenih radova prilagođene su opisu radova koji su obranjeni na visokim učilištima u Republici Hrvatskoj te trajnoj pohrani, korištenju i razmjeni, a usklađene su s međunarodnim normama i preporukama za opis ocjenskih radova. Kao temelj za sastavljanje specifikacija konzultirane su preporuke međunarodnih organizacija The Networked Digital Library of Theses and Dissertations (NDLTD) ${ }^{21}$, ETD Texas Digital Library $^{22}$ te Europeana Semantic Elements (ESE) ${ }^{23}$ i Europeana Data Model Documentation (EDM) ${ }^{24}$.

Kvaliteta pojedinog repozitorija i omogućivanje dostupnosti i vidljivosti radova osigurani su i kroz različite načine pregledavanja i pretraživanja. Tako je na ZIR-u omogućeno objedinjeno i vrlo jednostavno pronalaženje radova pregledavanjem po većini elemenata metapodataka, npr. po naslovu, autoru, ustanovi na kojoj je

18 Važno je napomenuti da se u ZIR pohranjuje posljednja obranjena verzija.

19 Metapodatkovni opis završnih i diplomskih radova. [citirano: 2018-03-15]. Dostupno na: https://dabar.srce.hr/files/ZIR-metapodaci-v1.7-2015-10-26.pdf.

20 Metapodatkovni opis disertacija. [citirano: 2018-03-15]. Dostupno na: https://dabar.srce.hr/ files/DR-metapodaci_V1_2015-12-04.pdf.

21 Nav.dj.

22 ETD Texas Digital Library. [citirano: 2018-03-20]. Dostupno na: https://www.tdl.org/etds/.

23 Europeana Semantic Elements (ESE). [citirano: 2018-03-15]. Dostupno na: https://pro.europeana.eu/page/ese-documentation.

24 Europeana Data Model. [citirano: 2018-03-15]. Dostupno na: https://pro.europeana.eu/resources/standardization-tools/edm-documentation. 
rad obranjen, sveučilištu kojem visoko učilište pripada, ključnim riječima itd. Sva je građa u ZIR-u indeksirana te je dostupna za napredno pretraživanje putem bilo koje riječi iz metapodataka i tekstova radova, npr. putem unosa naslova, autora, mentora, članova povjerenstava, URN:NBN-a itd. Preduvjet za uspješnu funkcionalnost svakog pojedinog repozitorija jest omogućivanje što boljeg ograničavanja rezultata pregledavanja i pretraživanja, odnosno implementacija fasetnog pretraživanja, što je prisutno u svim repozitorijima uspostavljenim na platformi Dabar.

Putem ZIR-a do ožujka 2018. godine dostupno je 57455 zapisa završnih i diplomskih radova, od čega je 26960 radova dostupno unutar ustanove, 23278 u otvorenom pristupu, 277 uz embargo, dok je 6929 radova potpuno zatvoreno za sve korisnike. U DR-u je vidljivo 1505 radova, od čega je njih 886 u otvorenom pristupu, 29 ih je dostupno uz embargo, 329 je potpuno nedostupno, a 248 je dostupno samo unutar ustanove. Razlog malog broja pohranjenih disertacija jest to što većina repozitorija još uvijek unosi samo završne i diplomske radove i pretpostavka je da nemaju riješena autorsko-pravna pitanja. ${ }^{25}$ Slika 3 prikazuje porast broja pohranjenih ocjenskih radova koji si vidljivi u nacionalnim repozitorijima. ${ }^{26}$

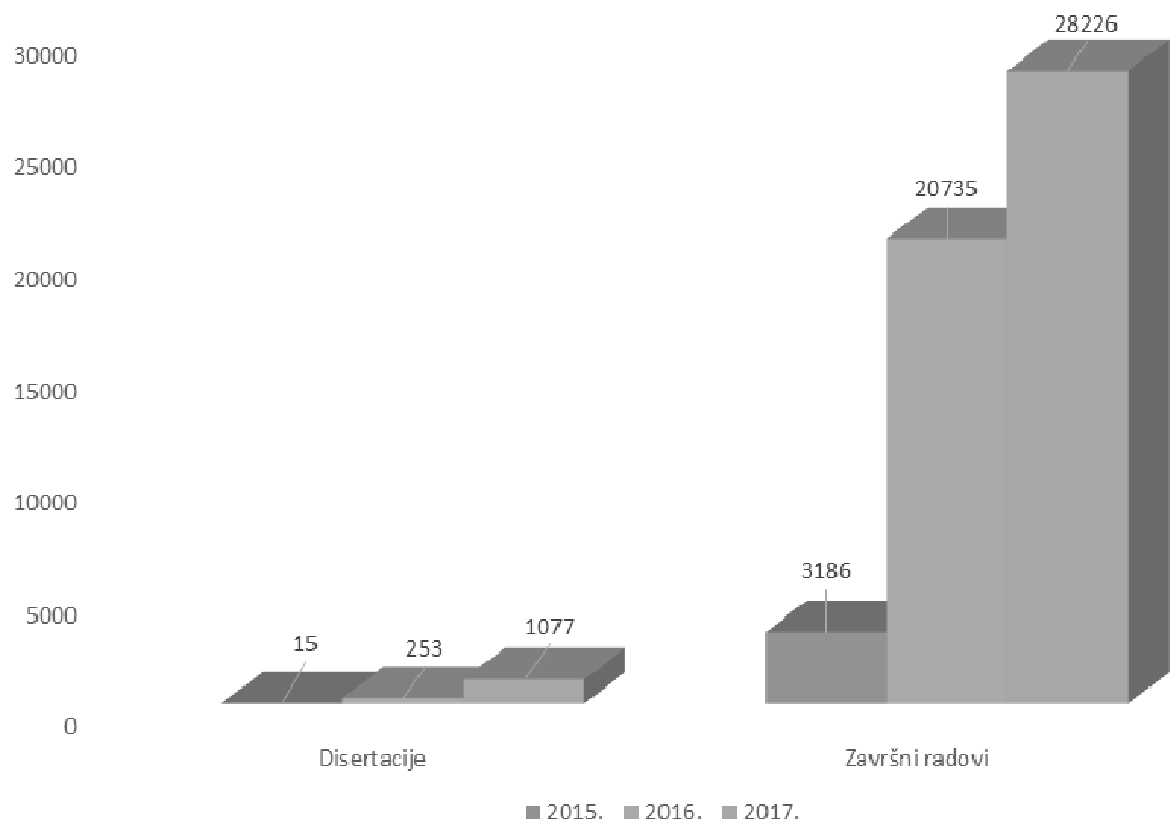

Slika 3. Broj disertacija i završnih radova (uključujući diplomske) u 2015., 2016. i 2017. godini

25 Do ožujka 2018. ukupno 41 repozitorij unosi i disertacije.

26 Podaci su dobiveni iz podataka u izvješćima o radu NSK. 


\section{Radni proces pohranjivanja ocjenskih radova}

Radni proces pohranjivanja ocjenskih radova u repozitorije u Dabru sastoji se od nekoliko koraka, pri čemu je naglasak stavljen na povezivanje repozitorija sa sustavima koje koriste visoka učilišta u Republici Hrvatskoj. Povezivanje omogućuje preuzimanje istovrsnih podataka koji već postoje u nekom drugom sustavu te se na taj način smanjuje redundantnost podataka, a cijeli se proces pohranjivanja ubrzava. Repozitoriji su tako povezani sa sustavom AAI@EduHr ${ }^{27}$, Informacijskim sustavom visokih učilišta RH (ISVU) ${ }^{28}$, Upisnikom studijskih programa $\mathrm{MZO}^{29}$, Upisnikom znanstvenika $\mathrm{MZO}^{30}$, Bazom podataka projektnih aktivnosti u znanosti i visokom obrazovanju $\mathrm{RH}^{31}$ te normativom OpenAIRE (Open Access Infrastructure for Research in Europe).

SustavAAI@EduHr autentikacijska je i autorizacijska infrastruktura sustava znanosti i visokog obrazovanja u Republici Hrvatskoj. Svaka ustanova uključena u sustav AAI@EduHr ima vlastitu bazu u kojoj su pohranjeni elektronički identiteti korisnika iz te ustanove, a podaci sadržani u elektroničkim identitetima korisnika koriste se i prilikom prijave te korištenja repozitorija u sustavu Dabar. U radnom procesu pohranjivanja ocjenskih radova podaci iz sustavaAAI@EduHr koriste se za ispunjavanje podataka o autoru ako je osoba koja pohranjuje rad ujedno $i$ autor tog rada.

Iz Upisnika studijskih programa MZO-a preuzimaju se podaci o studijskim programima visokog učilišta, a iz studijskog programa automatizmom se određuje smjer studija, razina studija, vrsta rada te akademski/stručni naziv.

Većina opisnih metapodataka ocjenskog rada preuzima se iz Informacijskog sustava visokih učilišta (ISVU):

- podaci o osobama (autor, mentor, članovi povjerenstva): ime, prezime, identifikator

- podaci o naslovu rada: naslov, naslov na drugom jeziku i podatak o jeziku

- podaci o voditeljima/mentorima: ime, prezime, identifikator, funkcija

- podaci o članovima povjerenstva: ime, prezime, identifikator

- datum obrane.

Važno je još istaknuti mogućnost povezivanja ocjenskih radova, najčešće disertacija, s projektima u okviru kojih su nastali, pri čemu se podaci o projektima

27 AAI@EduHr. [citirano: 2018-03-27]. Dostupno na: http://www.aaiedu.hr/.

28 ISVU. [citirano: 2018-03-27]. Dostupno na: http://www.isvu.hr/javno/hr/index.shtml.

29 Upisnik studijskih programa MZO. [citirano: 2018-03-27]. Dostupno na: http://mzos.hr/dbA$\mathrm{pp} /$ pregled.aspx?appName $=$ StudProgrami.

30 Upisnik znanstvenika MZO. [citirano: 2018-03-27]. Dostupno na: https://mzo.hr/hr/upisnik-znanstvenika-maticni-broj-znanstvenika.

31 Baza podataka projektnih aktivnosti u znanosti i visokom obrazovanju RH. [citirano: 2018-0604]. Dostupno na: https://pdb.irb.hr/. 
HRZZ-a i MZO-a preuzimaju iz Baze podataka projektnih aktivnosti u znanosti i visokom obrazovanju RH, dok se podaci o projektima financiranim od EC-a ili drugih financijera preuzimaju iz normativnog popisa projekata koji održava OpenAIRE.

Pomoću dohvaćenih podataka ispunjava se većina obrasca za opis ocjenskog rada te se od pohranitelja očekuje ručni unos u tek nekoliko polja (slika 4).

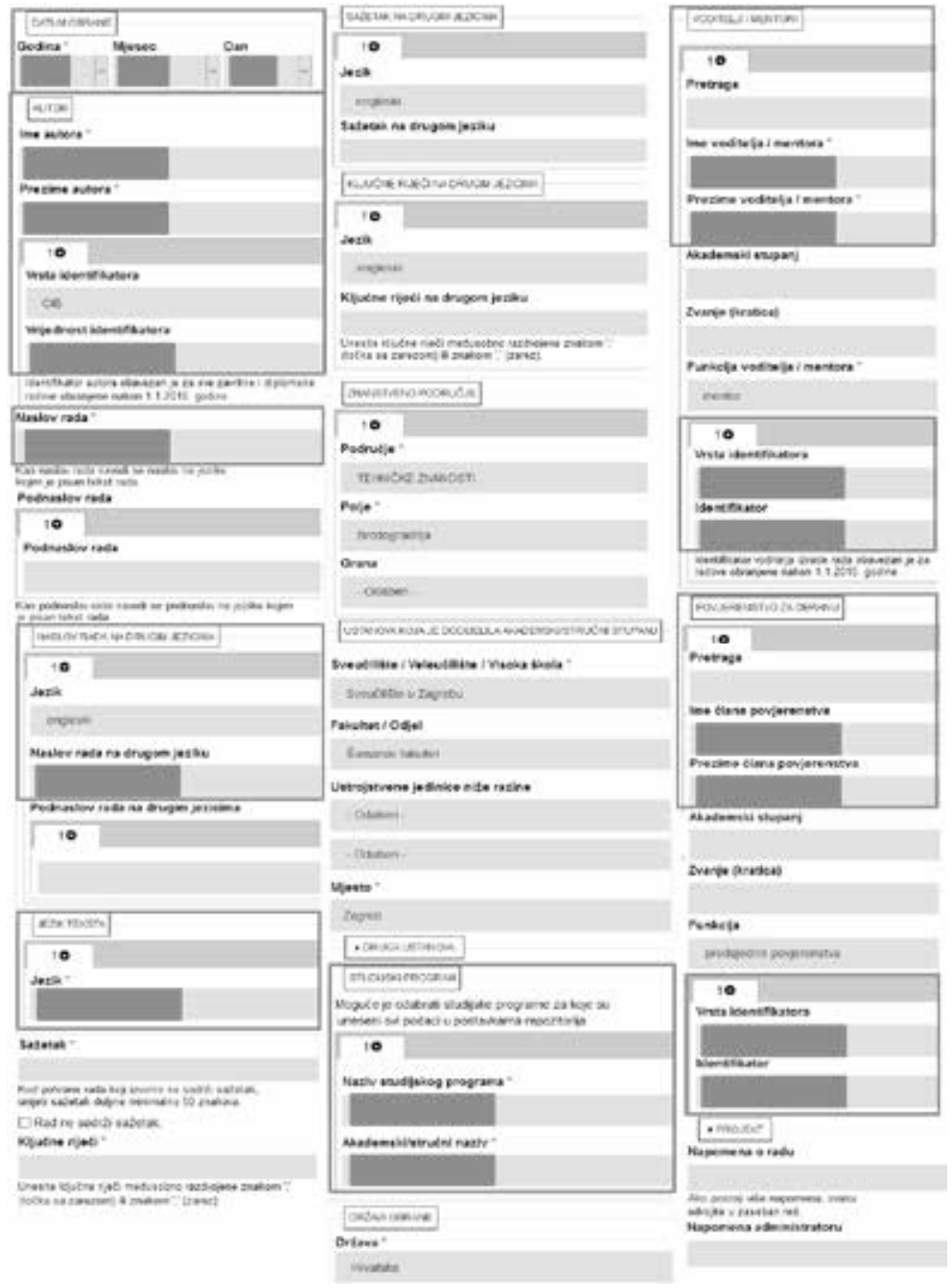

Slika 4. Prikaz obrasca za opis ocjenskog rada u repozitorijima u sustavu Dabar (crvenom bojom uokvirena su polja koja se automatizmom ispunjavaju podacima preuzetim iz ISVU-a, sustava AAI@EduHr, Upisnika znanstvenika MZO-a i Upisnika studijskih programa MZO-a) 
Ako se visoko učilište ne koristi Informacijskim sustavom visokih učilišta (ISVU), preuzimanje navedenih podataka nije moguće te je unos većinom ručni.

Po unosu metapodataka o radu potrebno je učitati cjeloviti dokument, nakon čega se te dvije stavke pohranjuju u repozitorij kao jedan digitalni objekt. Pritom objekt dobiva trajni identifikator URN:NBN, koji sadrži ime resursa (Uniform Resource Name) i garantira jedinstvenost i trajnost identifikacije, što je od izuzetne važnosti za citiranje radova i osiguravanje trajnog pristupa objektu, a dodjeljuje se u Nacionalnoj i sveučilišnoj knjižnici u Zagrebu. ${ }^{32}$ Postupak dodjele funkcionira na način da visoko učilište, nakon što ispuni uvjete koje određuje Srce, za otvaranje repozitorija popuni pristupnicu u sustav Dabar i javi se NSK-u za dodjelu URN:NBN-API-ključa. NSK nakon zaprimljene prijave te popunjenog i ovjerenog obrasca dodjeljuje ustanovi API-ključ i određeni namespace.

Pohranjivanje digitalnog objekta u repozitorij ujedno kreira nekoliko sljedova podataka (datastreams, slika 5) kao što su strojno čitljiv metapodatkovni opis u XML-formatu, status objekta, smanjena slika rada, cjelovit tekst rada izvučen iz PDF-a i sl.

Home , istundora Repository = Disertacije

Overvece

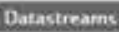

+ Add a datastream

\begin{tabular}{|c|c|c|c|c|c|}
\hline \multicolumn{6}{|c|}{ Uloga drultvenih mreta u predstavljanju hrvatskih visokolkolskih ustanova - sce :42 } \\
\hline ID & LABAL & VRSTA & MIME TYPE & SIZE & VERSIONS \\
\hline RELS-EXT & Federa Object to Object Relationship Metadate. & Inline XML & apglicatien/rdf=xml & 7748 & 5 \\
\hline MODS & MOOS R̂ecord & Managed & application $/ \mathrm{xml}$ & $14.08 \mathrm{KiB}$ & 2 \\
\hline DC & DC Record & Inline XML & text $/ \mathrm{xml}^{2}$ & $9.12 \mathrm{KiB}$ & 2 \\
\hline STATUS & STATUS & Maneged & text $/ \times m l$ & 2788 & 1 \\
\hline PDF & golubic_kruno_srese_2017_diser_sveuc_pdf & Managed & application/pdf & $4.19 \mathrm{MiD}$ & 1 \\
\hline IN & $\mathrm{TN}$ & Mansoed & image/jpeo & $1.18 \mathrm{~K} 18$ & 1 \\
\hline PREVIE & PREVIEW & Managed & image (jpeg & $11.9 \mathrm{KiB}$ & 1 \\
\hline FULL_TDT & FULL_TDXT & Maneoed & text/plain & $366.36 \mathrm{KiB}$ & 1 \\
\hline STATUS_INGEST & Ingest status log & Maneged & application/ $\mathrm{xml}$ & 4598 & 1 \\
\hline
\end{tabular}

Slika 5. Sljedovi podataka koji se kreiraju pohranom digitalnog objekta u repozitorij

32 Orešković, M. URN:NBN. // Dani digitalnih repozitorija. 2015. [Citirano: 2018-03-27]. Dostupno na: http://www.srce.unizg.hr/arhiva_weba/20160426/www.srce.unizg.hr/fileadmin/Srce/o_srcu/kalendar/DDR_2015/prezentacije/Oreskovic.pdf. 
Za razmjenu podataka s drugim sustavima i interoperabilnost repozitorija od izuzetne je važnosti strukturiran, detaljan i standardiziran metapodatkovni opis, najčešće u XML-formatu. Za opis objekata u repozitorijima u sustavu Dabar koristi se metapodatkovna shema Metadata Object Description Schema (MODS) Library of Congress ${ }^{33} \mathrm{~s}$ proširenjem iz Texas Digital Library Descriptive Metadata Guidelines for Electronic Theses and Dissertations ${ }^{34}$ te Dublin Core Metadata Element Set (DCMES). ${ }^{35}$

MODS je set metapodatkovnih elemenata koji se koristi za opis digitalnih objekata, a naročito za potrebe knjižnica i knjižnične građe, jer svaki element MODS-sheme odgovara barem jednom elementu sheme MARC 21. MODS se sastoji od 20 glavnih elemenata, pri čemu svaki od njih ima nekoliko podelemenata te mnogo atributa kojima se dodatno opisuje i precizira značenje vrijednosti koja se opisuje. Prilikom opisivanja digitalnog objekta elementima iz MODS-sheme od velike je važnosti prepoznati i dodijeliti semantički ispravan element za svaki metapodatak kako bi ga se nedvosmisleno odredilo te osiguralo da i ostali sustavi dobiju pravu informaciju o objektima.

Osim MODS-sheme, za opis digitalnih objekata koristi se i Dublin Core Metadata Element Set (DCMES). Dublin Core je set od 15 glavnih elemenata pomoću kojih se također metapodacima o digitalnom objektu pridodaje semantičko značenje. Dublin Core je sažet i nije toliko fleksibilan i proširiv kao MODS, no vrlo je prepoznatljiv i standardiziran set elemenata koji se koristi u razmjeni podataka u mnogim sustavima, pa se stoga koristi i u sustavu Dabar.

\section{Interoperabilnost zapisa ocjenskih radova}

Repozitoriji u sustavu Dabar prilagođeni su preuzimanju podataka iz drugih sustava, no također omogućavaju i drugim sustavima da preuzimaju podatke iz Dabra. Diseminacija informacija važna je funkcija repozitorija i stoga se posebna pažnja prilikom zapisivanja metapodataka pridaje korištenju standardiziranih kontroliranih rječnika i pripadajućih jedinstvenih identifikatora (URI, Uniform resource identifier) kako bi se prilikom razmjene podataka nedvosmisleno osiguralo ujednačeno i standardizirano semantičko značenje zapisanih metapodataka.

Kao primjer navedimo opis disertacija kojima se prilikom pohranjivanja moraju dodati autorove ključne riječi, no radi standardizacije opisa postoji mogućnost

\footnotetext{
33 Metadata Object Description Schema (MODS). [citirano: 2018-03-15]. Dostupno na: http:// www.loc.gov/standards/mods/.

34 Texas digital library descriptive metadata guidelines for electronic theses and dissertations. [citirano: 2018-03-20]. Dostupno na: https://tdl-ir.tdl.org/tdl-ir/handle/2249.1/68437.

35 Dublin Core Metadata Element Set (DCMES). [citirano: 2018-03-27]. http://dublincore.org/ documents/dces/.
} 
dodjeljivanja UDK-oznaka i predmetnica iz predmetnog sustava koji se koristi u određenom repozitoriju (MeSH, kontrolirani rječnik NSK i sl.).

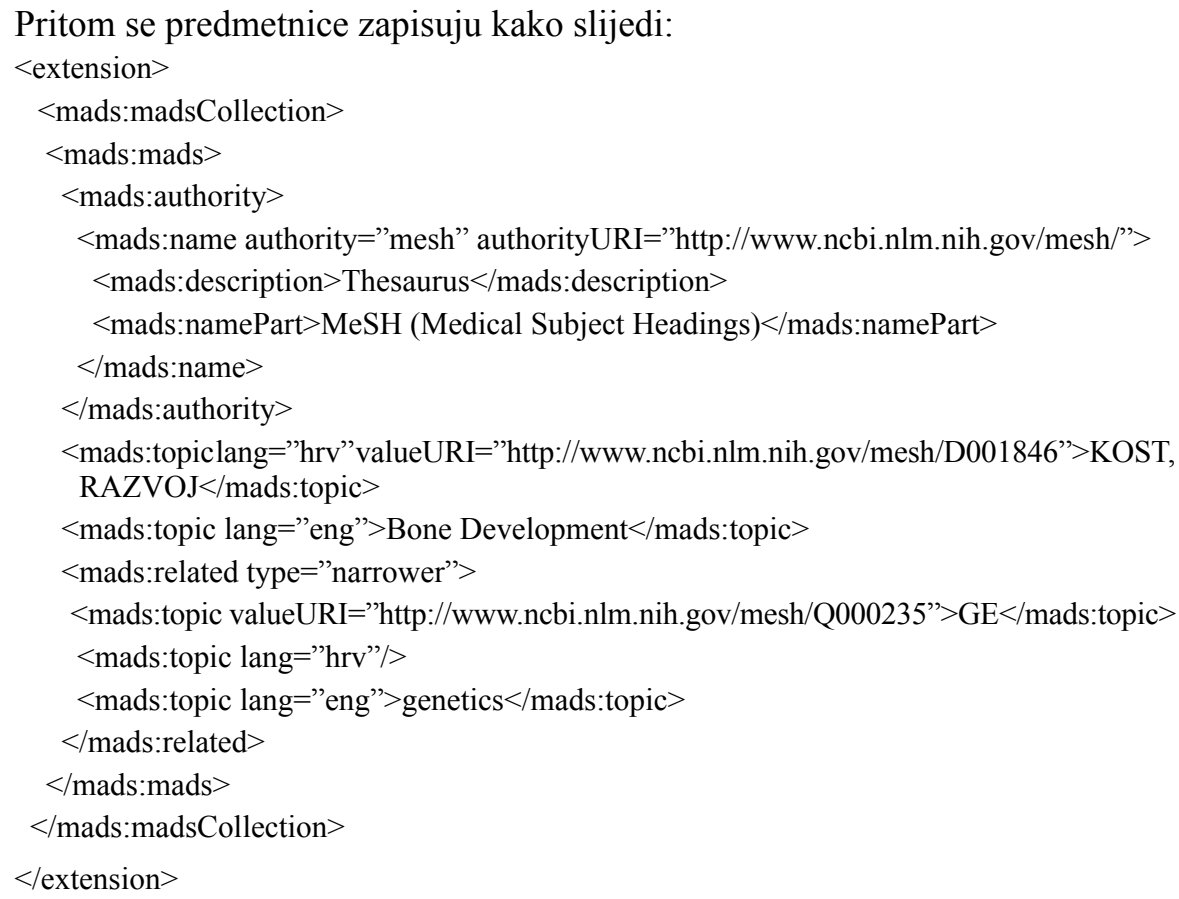

Iz ovog primjera vidljivo je bilježenje jedinstvenog identifikatora (URI) te detaljna granulacija termina koji se zapisuju na hrvatskom i engleskom jeziku. $\mathrm{Na}$ takav način pažljivo izrađeni zapisi ocjenskih radova temelj su za njihovu prepoznatljivost i indeksiranost, stoga se u izradu i nadzor zapisa ulaže mnogo truda i vremena.

Ocjenski se radovi u repozitorije Dabra, osim izravnim unosom i uz preuzimanje podataka iz prethodno spomenutih sustava, mogu pohranjivati putem REST API-sučelja koje omogućuje prenošenje ili kopiranje cjelovitih digitalnih objekata iz drugih sustava ili repozitorija u Dabar. ${ }^{36}$ Za korištenje REST API-sučelja vanjski sustavi ili repozitoriji moraju dostaviti svoje radove i pripadajuće metapodatke pripremljene sukladno specifikaciji Dabra za opis ocjenskih radova.

Nadalje, osim korisničkog sučelja, svi repozitoriji u Dabru imaju i OAI-PMH-sučelje. ${ }^{37}$ OAI-PMH (Open Archives Initiative Protocol for Metadata Harvesting) je

\footnotetext{
36 REST API-sučelje. [citirano: 2018-03-27]. Dostupno na: https://dabar.srce.hr/api.

37 OAI-PMH-sučelje repozitorija u Dabru nalazi se na adresi https://adresa-repozitorija-u-dabru/ oai.
} 
protokol za pobiranje metapodataka pohranjenih u repozitoriju, što osigurava prepoznatljivost repozitorija među vanjskim sustavima i njihovu interoperabilnost. ${ }^{38}$

Putem tog protokola repozitoriji su u funkciji davatelja podataka (engl. data providers) i izlažu metapodatke o građi koju sadrže kako bi ih drugi sustavi u funkciji pružatelja usluga (engl. service providers) mogli pobirati i nuditi na korištenje u okviru svoje usluge. OAI-PMH-sučelje uključuje dva niza standardiziranih metapodataka oblikovanih prema shemama MODS i Dublin Core (slika 6).

\section{OAI 2.0 Request Results}

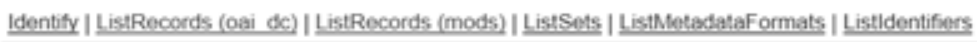

You are viewing an HTMI. version of the XMI. OAI response. To see the underlying XMI use your web browsers view source option.

$$
\begin{array}{|r|}
\text { Datestamp of response } 2018-05-24 \mathrm{~T} 08: 48: 47 \mathrm{Z} \\
\text { Request URL https://dr.nsk.hr/oai }
\end{array}
$$

Request was of type ListRecords.

OAI Record: oai:dr.nsk.hr:foi_1142

\section{OAI Record Header}

OAI Identifier oai:dr.nsk.hr:foi_1142 oai_de mods formats

Datestamp 2017-08-30T23:49:43Z

setSpec foi_disertacije Identifiers Records

\section{Metadata object descrion schema (MODS)}

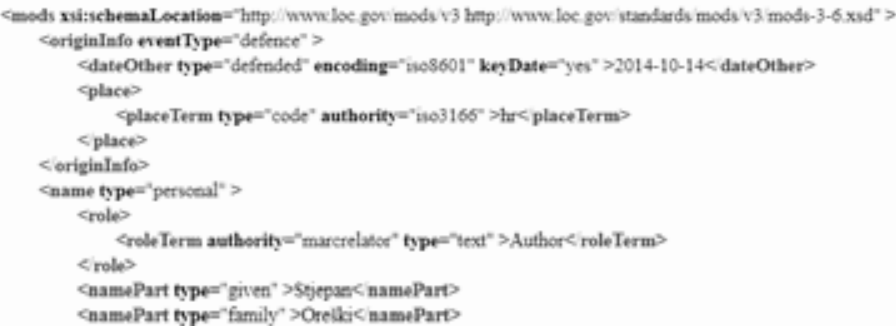

Slika 6. OAI-PMH sučelje Nacionalnog repozitorija disertacija i znanstvenih magistarskih radova (DR)

38 OAI-PMH. [citirano: 2018-03-27]. Dostupno na: https://www.openarchives.org/OAI/openarchivesprotocol.html. 
Sva OAI-PMH-sučelja repozitorija kompatibilna su sa smjernicama projekta OpenAIRE - OpenAIRE Guidelines for Literature Repository Managers 3.0, u kojima su navedena pravila za definiranje politika repozitorija, uređivanje i upravljanje podacima. ${ }^{39}$ Smjernice se prvenstveno odnose na minimalni metapodatkovni opis koji svaki digitalni objekt mora posjedovati, a riječ je o opisu koji se sastoji od sljedećih elemenata: Title $<\mathrm{dc}:$ title $>$, Creator $<\mathrm{dc}$ :creator $>$, Access Level $<$ dc:rights $>$, Publication Date $<\mathrm{dc}$ :date $>$, Publication Type $<\mathrm{dc}$ :type $>$, Resource Identifier $<$ dc:identifier $>$. Svi digitalni objekti u repozitorijima u Dabru opisani su navedenim elementima, kao i dodatnim elementima koji nisu obvezni (Subject $<\mathrm{dc}$ :subject>, Description <dc:description $>$, Contributor $<\mathrm{dc}$ :contributor $>$...), te su stoga repozitoriji u Dabru prilagođeni prijavi i diseminaciji svoje digitalne građe putem portala OpenAIRE.

OpenAIRE $^{40}$ je „H2020 projekt Europske komisije (EC) koji promiče provedbu otvorenog pristupa znanstvenim publikacijama i istraživačkim podacima i gradi europsku znanstveno-istraživačku infrastrukturu za pohranu, pronalaženje i ponovno korištenje rezultata istraživanja te na taj način unaprjeđuje vidljivost rezultata istraživanja projekata Europske komisije“. ${ }^{41}$ Kroz portal OpenAIRE registrirano je 10 repozitorija iz sustava $\mathrm{Dabar}^{42} \mathrm{u}$ funkciji davatelja podataka (engl. data providers), pri čemu su korisnicima na portalu dostupni metapodaci o radovima, a cjeloviti tekstovi preuzimaju se s izvornog repozitorija. Jedan od preduvjeta za prijavu u OpenAIRE jest prisutnost repozitorija u direktoriju OpenDOAR.

OpenDOAR (Directory of Open Access Repositories) ${ }^{43}$ je zbirni direktorij akademskih repozitorija u otvorenom pristupu. Važno je naglasiti da OpenDOAR ne prikuplja automatizmom repozitorije i podatke koje oni sadrže, nego je za prisutnost repozitorija u OpenDOAR-u potrebno ispuniti obrazac s osnovnim podacima o repozitoriju poput imena repozitorija, URL-adrese, vlasnika repozitorija, sjedišta vlasnika repozitorija itd. Prijave se evaluiraju, pa stoga OpenDOAR predstavlja važnu i autoritativnu bazu s više od 3500 akademskih repozitorija. Jedan od podataka koji se traže prilikom prijave jest i adresa OAI-PMH-sučelja repozitorija, koja je od velike važnosti za daljnje dijeljenje podataka trećoj strani, pri čemu OpenDOAR ima funkciju posrednika. Kroz OpenDOAR dostupna su 42 repozitorija sustava Dabar. ${ }^{44}$

\footnotetext{
39 OpenAIRE guidelines for literature repository managers 3.0. [citirano: 2018-03-20]. Dostupno na: https:/guidelines.openaire.eu/en/latest/literature/introduction.html.

40 OpenAIRE. [citirano: 2018-03-15]. Dostupno na: https://www.openaire.eu/.

${ }^{41}$ Interoperabilnost: OpenAIRE. [citirano: 2018-05-15]. Dostupno na: https://dabar.srce.hr/interoperabilnost.

${ }_{42}$ Podaci o broju repozitorija na dan 29. 3. 2018. dostupni su na https://www.openaire.eu/search/ data-providers\#pubRepo\#comp3\#text:croatia.

43 OpenDOAR. [citirano: 2018-03-15]. Dostupno na: [ http://www.opendoar.org/].

44 Podaci o broju repozitorija dostupni na dan 29. 3. 2018.
} 
Odredišne stranice digitalnih objekata u Dabru sadrže potrebne <meta> elemente prema smjernicama Google Scholar Inclusion guidelines for Webmasters ${ }^{45}$ i stoga su radovi iz repozitorija također dostupni putem Google znalca.

Također, putem OAI-PMH Nacionalnog repozitorija znanstvenih magistarskih radova i disertacija (DR) osigurava se dostava u središnji europski portal digitalnih disertacija DART-Europe ${ }^{46}$ DART-Europe je suradnički portal 28 ustanova članica s preko 120 repozitorija suradnika, uglavnom knjižnica i knjižničnih konzorcija. Zapisi koji postaju dijelom DART-Europea moraju sadržavati odgovarajuće OAI-PMH-sučelje koje uključuje zapise opisane prema shemi Dublin Core. Tako pripremljeni zapisi pobiru se dnevno. Važno je naglasiti da DART-Europe potiče otvoreni pristup te su stoga i podaci koji se indeksiraju i dostupni su putem portala isključivo zapisi u otvorenom pristupu. Iz Hrvatske je na dan 3. 4. 2018. putem portala DART-Europe bilo dostupno 1037 radova sa šest hrvatskih sveučilišta - Sveučilišta u Zagrebu, Sveučilišta u Rijeci, Sveučilišta Josipa Jurja Strossmayera u Osijeku, Sveučilišta u Splitu, Sveučilišta Jurja Dobrile u Puli i Sveučilišta u Zadru. ${ }^{47}$

Od 2017. godine zapisi iz Nacionalnog repozitorija znanstvenih magistarskih radova i disertacija (DR) dostupni su i u Europeani ${ }^{48}$, digitalnoj knjižnici, muzeju i arhivu europske kulturne baštine. Za dostupnost zapisa u Europeani jamči NSK. Metapodatkovni opisi disertacija sadrže sve elemente koji su potrebni za dostavu Europeani, poput vrste sadržaja, odnosno edm:type $(<\mathrm{dc} \text { :type }>\text { text }</ \text { dc:type }>)^{49}$, jezik $(<\mathrm{dc}$ :language $>$ hrv $</$ dc:language $>$ ), prava, podatke o repozitoriju, kao i poveznice na sam objekt za polje edm:isShownAt

( $<$ dc:identifier $>$ https://www.unirepository.svkri.uniri.hr/islandora/object/ ffri:354</dc:identifier $>$ ). Zapisi disertacija pobiru se povremeno na način da Europeanin pobirač pristupa OAI-PMH-sučelju disertacija nekoliko puta godišnje kada NSK dogovori razmjenu. Do ožujka 2018. u Europeani su se nalazila 1204 zapisa hrvatskih disertacija.

\footnotetext{
45 Google Scholar inclusion guidelines for webmasters. [citirano: 2018-03-27]. Dostupno na: https://scholar.google.com/intl/en/scholar/inclusion.html\#indexing.

${ }_{46}$ DART-Europe.[citirano: 2018-03-15]. Dostupno na: http://www.dart-europe.eu/About/info. php.

47 Redovitu dostavu disertacija u DART-Europe uspostavila je NSK u suradnji sa Srcem od prosinca 2016.

48 Europeana [citirano: 2018-03-27]. Dostupno na: https://www.europeana.eu/portal $/ \mathrm{hr} / \mathrm{sear}$ ch?q=europeana_collectionName\%3A\%289200133_NL_S2_Zagreb\%29.

49 Vrste sadržaja prema Europeani mogu biti: tekst, video, zvuk, slika, 3D.
} 


\subsection{Praćenje posjećenosti}

U sklopu mreže repozitorija u Dabru implementirano je praćenje statistika posjećenosti svim vrstama radova. Prikupljanje podataka za praćenje statistika posjećenosti i preuzimanja radova te njihovo upisivanje u bazu izradilo je Srce na vlastitom modulu Drupala koji prati, upisuje i dohvaća podatke iz baze, a za prikaz podataka, odnosno izradu grafova koristi se JavaScript Library (D3) $)^{50}$ te, povrh toga, i njegova nadogradnja JavaScript library $(\mathrm{C} 3) .{ }^{51}$

Nacionalni repozitoriji prate i posjećenost putem Google Analyticsa te je uočeno da se radovima pristupa sa svih kontinenata. Tako je primjerice na ZIR-u u 2017., što prikazuje i slika 7, broj online posjeta bio 344 118, s ukupno 827153 pregledane stranice, a posjetitelji su se zadržavali 1:38 minuta. Podaci o posjećenosti za DR su manji: broj online posjeta bio je 10746 , pregleda stranica 46017 , a korisnici su se na portalu zadržavali 2:47 minuta. Razlog je tomu još uvijek mali broj repozitorija koji pohranjuju disertacije te se taj podatak neminovno odražava i na samu posjećenost.

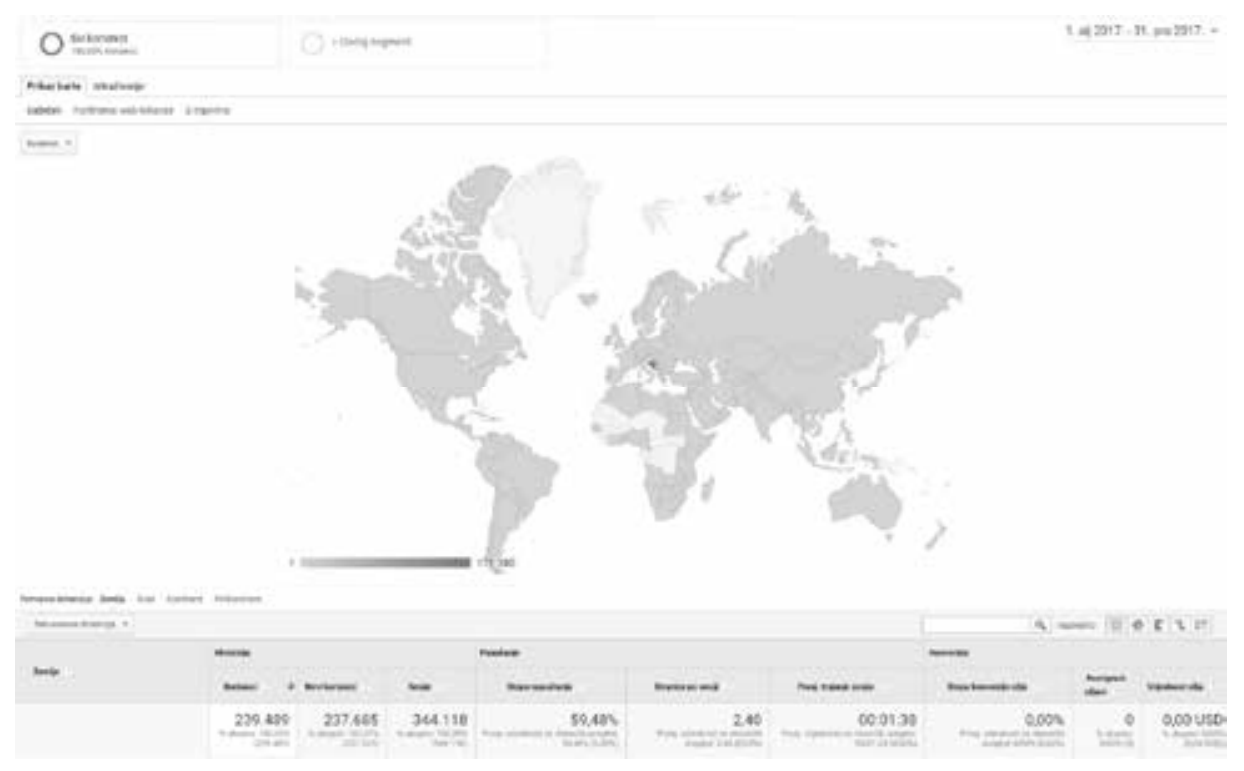

Slika 7. Podaci o posjećenosti ZIR-a u razdoblju od 1. 1. 2017. do 31. 12. 2017. prema Google Analyticsu

50 Više informacija o JavaScript library (C3) dostupno je na https://d3js.org.

51 Više informacija o JavaScript library (D3) dostupno je na http://c3js.org/. 


\section{Zaključak}

Održivost repozitorija za prihvat, obradu, pohranu, čuvanje i korištenje ocjenskih radova u digitalnom obliku u Dabru u velikoj je mjeri osigurana jer se temelji na zakonskoj podlozi i sadrži odgovarajuću infrastrukturu, standardizirane metapodatkovne opise, korištenje kontroliranih rječnika, trajnih identifikatora, dobro strukturirane elemente itd. Na taj je način omogućeno jednostavnije pronalaženje i dostupnost, kao i otvorenost repozitorija te buduća istraživanja, ali i povezivanje i razmjena s drugim sustavima. Pozicioniranje repozitorija u međunarodnim bazama također ovisi o količini, dostupnosti i otvorenosti radova.

Daljnji planovi razvoja Dabra uključuju bolju podršku za ORCID-identifikatore autora, indeksiranje u pretraživačima (EBSCO, ProQuest, Summoni sl.), povezivanje s novim informacijskim sustavom u znanstvenoj djelatnosti CroRIS, preuzimanje metapodataka iz baze PubMed Central itd.

Osim navedenih planova koji dodatno doprinose interoperabilnosti repozitorija, u planu je intenzivan razvoj podrške za pohranjivanje raznih digitalnih objekata, osiguravanje dugoročnog očuvanja tekstualnih datoteka u PDF/A-formatu, unapređivanje statističkih prikaza na repozitorijima te druge korisničke funkcionalnosti sukladno zahtjevima i potrebama zajednice.

\section{LITERATURA}

AAI@EduHr. [citirano: 2018-03-27]. Dostupno na: http://www.aaiedu.hr/.

Baza podataka projektnih aktivnosti u znanosti i visokom obrazovanju RH. [citirano: 2018-06-04]. Dostupno na: https://pdb.irb.hr/.

Celjak, D.; Z. Bekić; Lj. Jertec; M. Milinović; D. Ulamec. Dabar - sustav digitalnih repozitorija: iskorak prema sustavnoj brizi za digitalnu imovinu akademske zajednice u Hrvatskoj. // Arhivi, knjižnice, muzeji 18(2015), 148-165. [citirano: 2018-04-05]. Dostupno na: https://hrcak.srce.hr/ojs/index.php/akm/article/view/3746.

Dabar. [citirano: 2018-04-05]. Dostupno na: https://dabar.srce.hr/.

DAR. [citirano: 2018-03-15]. Dostupno na: http://dar.nsk.hr/.

DART-Europe. [citirano: 2018-03-15]. Dostupno na: http://www.dart-europe.eu/About/ info.php.

Dublin Core Metadata Element Set (DCMES). [citirano: 2018-03-27]. http://dublincore. org/documents/dces/.

ETD Texas Digital Library. [citirano: 2018-03-20]. Dostupno na: https://www.tdl.org/ etds/. 
Europeana [citirano: 2018-03-27]. Dostupno na: https://www.europeana.eu/portal/hr.

Europeana Data Model. [citirano: 2018-03-15]. Dostupno na: https://pro.europeana.eu/ resources/standardization-tools/edm-documentation.

Europeana Semantic Elements (ESE). [citirano: 2018-03-15]. Dostupno na: https://pro. europeana.eu/page/ese-documentation.

Interoperabilnost: OpenAIRE. [citirano: 2018-05-15]. Dostupno na: https://dabar.srce. $\mathrm{hr} /$ interoperabilnost.

ISVU. [citirano: 2018-03-27]. Dostupno na: http://www.isvu.hr/javno/hr/index.shtml.

Konjević, S. Ocjenski radovi u digitalnom obliku. // Kemija u industriji 59,-9(2010), 452-456.

Metadata Object Description Schema (MODS). [citirano: 2018-03-15]. Dostupno na: http://www.loc.gov/standards/mods/.

Metapodatkovni opis disertacija. [citirano: 2018-03-15]. Dostupno na: https://dabar. srce.hr/files/DR-metapodaci_V1_2015-12-04.pdf.

Metapodatkovni opis završnih i diplomskih radova. [citirano: 2018-03-15]. Dostupno na: https://dabar.srce.hr/files/ZIR-metapodaci-v1.7-2015-10-26.pdf.

Nacionalni repozitorij disertacija i znanstvenih magistarskih radova (DR). [citirano: 2018-03-15]. Dostupno na: https://dr.nsk.hr/.

Nacionalni repozitorij završnih i diplomskih radova (ZIR). [citirano: 2018-03-15]. Dostupno na: https://zir.nsk.hr/.

Networked Digital Library of Theses and Dissertations (NDLTD). [citirano:2018-03-20]. Dostupno na: http://www.ndltd.org/.

OAI-PMH . [citirano: 2018-03-27]. Dostupno na: https://www.openarchives.org/OAI/ openarchivesprotocol.html.

OpenAIRE. [citirano: 2018-03-15]. Dostupno na: https://www.openaire.eu/.

OpenAIRE guidelines for literature repository managers 3.0. [citirano: 2018-03-20]. Dostupno na: https://guidelines.openaire.eu/en/latest/literature/introduction.html.

OpenDOAR. [citirano: 2018-03-15]. Dostupno na: [http://www.opendoar.org/.

Orešković, M. URN:NBN. // Dani digitalnih repozitorija. 2015. [Citirano: 2018-03-27]. Dostupno na: http://www.srce.unizg.hr/arhiva_weba/20160426/www.srce.unizg.hr/ fileadmin/Srce/o_srcu/kalendar/DDR_2015/prezentacije/Oreskovic.pdf.

REST API sučelje. [citirano: 2018-03-27]. Dostupno na: https://dabar.srce.hr/api.

Texas digital library descriptive metadata guidelines for electronic theses and dissertations. [citirano: 2018-03-20]. Dostupno na: https://tdl-ir.tdl.org/tdl-ir/handle/2249.1/68437.

Upisnik studijskih programa MZO. [citirano: 2018-03-27]. Dostupno na: http://mzos.hr/ $\mathrm{dbApp} /$ pregled.aspx?appName $=$ StudProgrami. 
Upisnik znanstvenika MZO. [citirano: 2018-03-27]. Dostupno na: https://mzo.hr/hr/ upisnik-znanstvenika-maticni-broj-znanstvenika.

Zakon o izmjenama i dopunama Zakona o znanstvenoj djelatnosti i visokom obrazovanju. // Narodne novine 94, 2132(2013). [citirano: 2018-03-20]. Dostupno na: http:// narodne-novine.nn.hr/clanci/sluzbeni/2013_07_94_2132.html. 